Warszawskie Studia Pastoralne UKSW

Rok XI 2016 Nr 3 (32)

KaRD. WALter Kasper

(Rzym)

\title{
MIŁOSIERDZIE W PRAWIE KOŚCIOŁA
}

Zagadnienie sprawiedliwości pojawiło się ponownie na rzymskim Synodzie Biskupów poświęconym rodzinie w 2015 r. w związku z problemem osób rozwiedzionych żyjących w nowych związkach. Powstało pytanie: jak w praktyce należy stosować obowiązującą naukę Kościoła, aby była ona sprawiedliwa i jednocześnie słuszna oraz sprawiedliwa, ale i miłosierna? Na ten ważny pod wieloma względami temat, chciałbym przedłożyć pewne refleksje, nie tracąc z oka teologicznie zasadniczej perspektywy.

\section{Prawo i sprawiedliwość}

Zacznę od tezy, że pokój na świecie, w państwie i w każdej wspólnocie, także w Kościele, możliwy jest tylko w oparciu o sprawiedliwość (por. Iz 32,17): opus justitiae pax. Według św. Augustyna państwo bez sprawiedliwości pozostaje jedynie wielką bandą zbójców (por. Civ. Dei IV, 4). Możemy być wdzięczni, o ile żyjemy w państwie prawa, gdzie nie obowiązuje prawo pięści, nie ma miejsca dla samowoli państwa i jego władzy, gdzie zgodnie z prawem i sprawiedliwością podejmuje się decyzje, gdzie w razie potrzeby można je zaskarżyć odwołując się od niesłusznego wyroku.

Czymże jest sprawiedliwość? Według starej i do dziś uznawanej definicji sprawiedliwość oznacza: oddać każdemu co jego (suum cuique). „Sprawiedliwość jest to stała i niezłomna wola oddawania każdemu tego, co mu się należy." (Ulpian). Tym samym wszelkie egoistyczne roszczenia oraz wszelkie absolutystyczne czy wręcz totalitarne pretensje mają swoje granice, zaś każdemu zapewnia się przysługującą 
mu przestrzeń wolności, ustanawiając tym samym porządek oparty na wolności i pokoju. Trudno jest wszakże rozstrzygnąć co należy się innym; nie sposób jednoznacznie powiedzieć co jest moje, co jest twoje, co nasze, a co innych? Jaka jest sprawiedliwa zapłata, jakie winno być sprawiedliwe wynagrodzenie? Co nie tylko jest prawem zobowiązującym, ale też prawem sprawiedliwym? Czym jest sprawiedliwość społeczna, sprawiedliwość szans, sprawiedliwość pokoleń, sprawiedliwość między krajami biednymi a bogatymi? Czy można mówić o wojnie sprawiedliwej?

Co konkretnie oznacza sprawiedliwość i według jakiej miary należy ją mierzyć okazuje się bezsporne do czasu następnej kampanii wyborczej. Wszyscy pragną i obiecują pełną sprawiedliwość, ale rozumieją ją różnie. Niektórzy są przekonani, że sprawiedliwość jest pustą formułą i po prostu fasadą słowną. Inni zaś twierdzą, że konkretną treść pojęcia sprawiedliwości można wypracować w publicznym dyskursie doprowadzając do konsensu przez zachowanie względnej równowagi między prawami podstawowymi każdego człowieka a różnymi interesami, dobrami i szansami.

Brzmi to dobrze, ale odwołuje się do społeczeństwa utopijnego, w którym każdy przekonany jest o równych prawach każdego człowieka, niezależnie od jego narodowej, etnicznej, religijnej, społecznej i klasowej przynależności, i w którym każdy jest gotów, aby te niesprawiedliwe stosunki naprawić, uznając za uprawnione interesy innych. Takim nasz świat jednak nie jest. Nie tylko bowiem nie sposób osiągnąć pełną sprawiedliwość, ale już trudno o całkowitą zgodność co do sposobu jej rozumienia.

Już kompletnie kuriozalnie brzmi domaganie się sprawiedliwości przy jednoczesnej - wołającej o pomstę do nieba - niesprawiedliwości, jak choćby w przypadku masowych mordów czy eksterminacji całych narodów. Żadna ludzka sprawiedliwość nie zdoła naprawić niesprawiedliwości holokaustu, choćby częściowo. Ewentualne działania odwetowe, prowadziłyby do nowych niesprawiedliwości: wyzwalając przemoc rodzą kontrprzemoc. Sama zresztą sprawiedliwość nie zapewnia pokoju. Spór o sprawiedliwość na ogół prowadzi do niepokojów i nowej niesprawiedliwości. 


\section{Rewolucja proroków}

Dotychczasowe uwagi prowadzą nas do sposobu rozumienia sprawiedliwości w kulturach starożytnego Wschodu, choćby w teorii Ma’at starożytnego Egiptu. Tutaj sprawiedliwość ugruntowana jest w boskim porządku kosmicznym, który został ustanowiony dla nas, ludzi, a równocześnie dany nam do urzeczywistnienia. W kulturach starożytnych sprawiedliwość ma wymiar religijny. Podobnie jest w Starym Testamencie: sprawiedliwy to ktoś, kto się boi Boga, jest pobożny, zachowuje Boże przykazania i Boże Przymierze. Sprawiedliwość oznacza wierność Przymierzu. I tak czytamy u proroka Micheasza: „Powiedziano ci, człowiecze, co jest dobre. I czegoż żąda Pan od ciebie, jeśli nie pełnienia sprawiedliwości, umiłowania życzliwości i pokornego obcowania z Bogiem twoim" (Mi 6,8).

Gdzie naruszony zostaje kosmiczny porządek czy wierność Przymierzu, tam kosmiczny porządek czy Przymierze Boga ze swoim ludem wystawione są na niebezpieczeństwo. Sprawiedliwość domaga się przywrócenia, sprawiedliwego wyrównania: „oko za oko, ząb za ząb” (Wj 21,24). Zamiast ofiary z człowieka składane są ofiary zastępcze ze zwierząt. Najbardziej znana jest ofiara z kozła ofiarnego, na którego nakłada się winy ludu, a wypędzając go na pustynię, skazuje się na śmierć zastępczą (Kpł 4-5; 16). Tylko w ten sposób można powstrzymać karzący gniew Boga i przywrócić sprawiedliwość. Kara musi być sprawiedliwa, aby ocalić porządek całości i życie wszystkich. Takie praktyki powodowały również w Starym Testamencie straszne akty przemocy.

Dopiero rewolucja proroków do głębi wstrząsnęła obrazem świata starożytnego Wschodu, w tym również starożytnego Izraela. Następuje ona $\mathrm{z}$ objawieniem danym Mojżeszowi. Krótko po zawarciu Przymierza na Synaju, zostaje ono zerwane, gdyż lud okazuje się niewierny; tańcząc wokół złotego cielca, zwraca się ku obcemu bogu. Bóg za sprawą Mojżesza zmuszony zostaje do nadzwyczajnego działania. Oto objawia się mu jako Ktoś całkowicie inny: „Jahwe jest Bogiem miłosiernym i łaskawym, cierpliwym i bogatym w łaskawość i wierność" (Wj 34,6). To zdanie staje się w Starym Testamencie ciągle powracającym refrenem. Oznacza, że Bóg Izraela jest zupełnie 
inny: nie jest On mściwy, nie jest Bogiem karzącym, lecz cierpliwym i miłosiernym.

Ów rewolucyjny obraz Boga znajduje swój najbardziej wymowny i jednoznaczny wyraz u proroka Ozeasza. Ta rewolucyjność tkwi dramatycznie w samym Bogu. Bóg wyzbywa się swej sprawiedliwości - by tak rzec - na rzecz ludu; miłosierdzie tryumfuje nad sprawiedliwością. Dlaczego? Odpowiedzią jest stwierdzenie: „Jestem Bogiem, nie człowiekiem" (Oz 11,8). Jestem ponad wszystkim i transcendentny, nie związany waszymi wyobrażeniami o zadość czyniącej sprawiedliwości; sprawiedliwy jestem tylko wobec siebie samego, pozostając wiernym wobec siebie samego. Ponieważ Bóg jest miłością - jak dowiadujemy się później z Nowego Testamentu (por. 1 J 4,8.16), musi być zupełnie inny od człowieka, który Go przyzywa, prosząc o miłosierdzie i wybaczenie win. Miłosierdzie jest wiernością Boga samemu sobie. W miłosierdziu manifestuje się sama najgłębsza Istota Boga. Boża sprawiedliwość jest Jego miłosierdziem. To miłosierdzie jest imieniem naszego Boga.

\section{Miłosierdzie stwarza nowy porządek}

Miłosierdzie Boga oznacza, że ma On serce dla człowieka będącego w potrzebie. Misericordia to mieć serce (cor) dla miseri, a więc żyjących w nieszczęściu. W taki oto sposób Bóg objawia się w gorejącym krzewie. Dostrzega nieszczęście i słyszy krzyk skargi (Wj 3,7). Miłosierdzie jest jednak czymś więcej niż współczuciem; jest czynnym sprzeciwem wobec zła. Dlatego Bóg wyprowadza swój lud z niewoli egipskiej. Nie oczekuje rekompensaty, restytucji starego porządku na wyobrażenie starożytnego Wschodu. Stwarza nowy porządek i ofiarowuje nowy początek.

To może tylko Bóg. My, ludzie, bowiem nie jesteśmy w stanie wydobyć się z tego stanu. Zawsze pozostajemy związani z naszą przeszłością oraz determinującymi nas aktualnymi warunkami. Ale Bóg jest absolutny, a Jego moc ujawnia się przede wszystkim w pojednaniu i przebaczeniu (oracja z 26 Niedzieli w roku liturgicznym). Miłosierdzie stwarza nowy porządek, owo nowe stworzenie, które będąc ordo amoris jest większe od pierwszego stworzenia. 
Nikt jak św. Tomasz z Akwinu nie wydobył tak po mistrzowsku tej współzależności. Dla Tomasza bowiem miłosierdzie ma pierwszeństwo przed sprawiedliwością; jest ono wyrazem wielkości i suwerenności Boga (S. th. I,21,1-4). Przebaczenie jest dziełem większym niż dzieło stworzenia (I/II, 113,9). Nie znosi ono sprawiedliwości, lecz właśnie ją przywraca, gdzie po ludzku wydaje się być nieodwołalnie zniszczona i nieprzywracalna. Nie usprawiedliwia zła, ale usprawiedliwia zło gotowe się nawrócić; nie grzech, ale grzesznika przez danie mu nowej szansy.

Toteż nie możemy uczynić miłosierdzia wymówką dla braku sprawiedliwości; sprawiedliwość jest - by tak rzec - minimum miłosierdzia, które to minimum winni jesteśmy innym. Jest ono wyższą sprawiedliwością (por. Mt 5,20). Jezus mówi, że zarówno szczęśliwym jest miłosierny, jak i ci, którzy pragną i łakną miłosierdzia (por. Mt 5,6n). Raz jeszcze przywołajmy Tomasza z Akwinu: sprawiedliwość bez miłosierdzia jest okrucieństwem, miłosierdzie bez sprawiedliwości matki wszelkich rozwiązań, byłoby ono chaosem (In ev. Matth. cap. 5,2).

Miłosierdzie nie znosi sprawiedliwości, ale czyni, że jest na nowo możliwa. Usprawiedliwia nie grzechy, lecz grzesznika, który zawsze od nowa może postępować słusznie. Jest ono Bożą opcją wobec śmierci i jej władzy oraz opcją na rzecz życia. Bóg bowiem nie chce śmierci grzesznika, na którą zasługuje, lecz chce, by on żył (por. Ez 33,11). Bóg jest „Przyjacielem życia” (Mdr 11,26).

\section{Wiodący motyw przepowiadania}

W Kościele ciągle chodzi o granice sprawiedliwości i miłosierdzia. Nie jest to jakiś problem drugorzędny. Chodzi o pytanie zasadnicze: kim jest Bóg i kim my jesteśmy przed Bogiem? Jest to zasadnicza misja Kościoła.

Po Vaticanum II Kościół rozumie się jako sakrament, to znaczy jako znak i narzędzie zbawienia poszczególnych osób jak i całej ludzkości (LG 1 i in.). Oznacza to, że jest on również znakiem i narzędziem miłosierdzia Bożego. Bycie miłosiernym, jak miłosiernym jest nasz Ojciec w niebie, obowiązuje nie tylko poszczególnego chrześcijanina, 
ale także Kościół (por. Łk 6,35). Byłoby źle, gdyby sami członkowie Kościoła uznawali go za niemiłosierny!

Dla postępowania Kościoła wielkie znaczenie zachowuje przypowieść o zaginionym synu czy właściwiej: o miłosiernym Ojcu (Łk 15,1132) oraz przypowieść o miłosiernym Samarytaninie (Łk 10,25-37). Zgodnie z tym, co powiedział papież Franciszek, miłosierdzie musi stać się filarem nośnym wszelkiej praktyki Kościoła (Misericordiae vultus; Jezus Chrystus obliczem miłosierdzia Ojca, 2015). Dlatego za skandal trzeba uznać częste przedstawianie w przeszłości obrazu Boga jako skorego do wymierzania kary oraz mściwego. Toteż jest skandalem, że wielu postrzega Kościół jako pozbawiony miłosierdzia, nie widząc w nim powabnej Oblubienicy Chrystusa i miłosiernej Matki, ale moralizatorską, zgorzkniałą starą pannę. Byłoby to najgorszym skandalem, gdyby taki wizerunek miał się utrzymać.

Miłosierdzie musi być głównym motywem przewodnim przepowiadania Kościoła; powinno być ono kwintesencją jego sakramentalnej praktyki, zwłaszcza sakramentu przebaczenia i pojednania, ale też Eucharystii, ustanowionej przecież na przebaczenie grzechów, nie zaś jako nagroda dla doskonałych chrześcijan czy tych, którzy za takich się uważają (por. Ewangelii gaudium, nr 47). Miłosierdzie musi być zasadniczym impulsem i motywacją charytatywnego i socjalnego działania Kościoła, a wreszcie wiodącą zasadą jego porządku prawnego.

\section{Słusznie i sprawiedliwie}

Kościół nigdy nie był, także w swych apostolskich początkach, czystym Kościołem ducha czy czystym Kościołem miłości. Przeciwieństwem Kościoła prawa nie byłby Kościół miłości, lecz Kościół bezprawia. Prawo Kościoła odnajduje swój fundament w Piśmie Świętym, w najbardziej wyrazisty sposób w danej Piotrowi i wszystkim Apostołom obietnicy: „Co zwiążecie na ziemi, będzie związane w niebie, a co rozwiążecie na ziemi, będzie rozwiązane w niebie (Mt 16,19; 18,18). Ta tak zwana władza kluczy sięga do prawa rabinicznego, które przez akt zgody bądź zakazu odpowiednio przywraca kogoś do 
wspólnoty bądź z niej wyklucza, a więc ma miejsce akt rekoncyliacji albo ekskomunikowania.

Że nie tyle chodzi tu o zewnętrzne pełnomocnictwo prawne, wynika ze stwierdzenia, iż to, co zdarza się na ziemi, posiada ważność także w niebie. Chodzi zatem o duchową władzę w służbie zbawczej ludzi. W wersji Janowej owo pełnomocnictwo wyraża się władzą, jaką Zmartwychwstały przekazuje swoim uczniom, by mocą Ducha Świętego mogli udzielać grzesznikom przebaczenia bądź zatrzymywać im ich grzechy, to jest nie udzielać im przebaczenia (por. J 20,23).

Tradycja kanoniczna w swych wielkich reprezentantach świadoma była duchowego i duszpasterskiego charakteru tego prawnego pełnomocnictwa. Także obowiązujące prawo kanoniczne ma zapis, że zbawienie dusz jest najwyższą normą wszelkiego prawa i wszelkiej wykładni prawa w Kościele (por. KPK/1983 kan. 1752). Toteż kanonistyka rozwinęła teorię aplikacji prawa Kościoła. Mówi się tu (jak w przywołanym kanonie) o słuszności kanonicznej (aequitas canonica). Kanoniczny przepis prawny winien być stosowany nie tylko sprawiedliwie, ale też i słusznie; jego zastosowanie musi być sprawiedliwe i słuszne.

Wraz z pojęciem słuszności (aequitas) prawo kanoniczne przejęło pojęcie należące do grecko-rzymskiej kultury prawnej. Już filozof grecki Arystoteles, który dla myśli Zachodu ma niekwestionowane znaczenie, wiedział, że każde prawo ogólne ma luki, gdyż nie może uwzględnić wszystkich możliwych okoliczności poszczególnego przypadku (Eth V. 1137 b). Aequitas zapewnia sprawiedliwość w poszczególnym przypadku; nie znosi ona prawa ogólnego, nie dodaje też żadnych wyjątków, ale w indywidualnych przypadkach stosuje prawo w sposób słuszny. Bardzo legalistycznie pojmowana sprawiedliwość może - jak mawiali Rzymianie (Cicero, De off. I,33) a Jan Paweł II z aprobatą przywołał - stać się summum ius summa iniuria (najwyższe prawo największą niesprawiedliwością).

\section{Oczami miłosierdzia}

Średniowieczna kanonistyka naukę o aequitas interpretowała jako umiar, łagodność, miłosierdzie. Nazywała aequitas sprawiedliwością 
miarkowaną słodyczą miłosierdzia (Dekret Gracjana, XII w.). Miłosierdzie osładza niejako sprawiedliwość. Nie oznacza to, że miłosierdzie jest „miękką spłuczką” sprawiedliwości. Przeciwnie: miłosierdzie domaga się w konkretnej sytuacji dynamicznego - a przez to sprawiedliwego - stosowania prawa w służbie zbawczej człowieka.

Miłosierdzie jest - by tak rzec - słuszną, chrześcijańską miarą urzeczywistniania sprawiedliwości. Dzięki niemu człowieka nie uważa się za przypadek prawny i nie skazuje się go na gilotynę. Ogląda się go oczami miłosierdzia i traktuje z miłosierdziem, co pozwala na wyrównanie niesprawiedliwości zapewniając nowe szanse. Prawo nie ma przy tym charakteru odwetowego, ale leczniczy i zbawczy. Zawieszenie kary prowadzi do refleksji i umożliwia nowy początek.

Z takiego spojrzenia papież Jan XXIII w swym znanym przemówieniu na otwarcie Soboru Watykańskiego II 11 października 1962 uczynił program i motyw przewodni tego Zgromadzenia, a tym samym posoborowego Kościoła. Powiedział wówczas, że nie chodzi dziś, by sięgać po oręże surowości, ale by uciec się do lekarstwa miłosierdzia. Papież Franciszek ogłaszając Rok Miłosierdzia wpisał się w tę linię Soboru. Tym samym wprowadza on nowy etap soborowej recepcji, oznaczającej konkretne urzeczywistnianie Soboru.

Podobnie jak Jan XXIII na początku Soboru mówił o miłosierdziu, tak i Paweł VI w swej mowie kończącej Sobór 7 grudnia 1965. Na pytanie czym jest duchowość Soboru, odpowiedział: duchowością dobrego Samarytanina. A Jan Paweł II, który w Polsce przeżył całą okropność nazizmu a potem czasy komunizmu, swą drugą encyklikę poświęcił Bożemu miłosierdzi (Dives in misericordia, Bóg bogaty w miłosierdzie, 1980). Ponieważ wszystkich tych wołających o pomstę do nieba nieprawości żaden człowiek nie jest w stanie naprawić i im zadośćuczynić, pozostaje tylko powierzyć je Bożemu miłosierdziu. Benedykt XVI swoją pierwszą encyklikę zatytułował Deus caritas est (Bóg jest miłością, 2005). Papież Franciszek przejął wszystkie te impulsy swoich Poprzedników i kontynuuje je. W liście apostolskim Mitis Iudex Dominus Jesus (Łagodny Sędzia Pan Jezus, 15 sierpnia 2015) przed oczyma kościelnych sędziów postawił za wzór Łagodnego Sędziego - Jezusa. 


\section{Sprawiedliwość sytuacyjna}

Wraz z tym listem apostolskim stoimy wobec aktualnego pytania, dyskutowanego przed i w czasie Synodu: w jaki sposób ów główny motyw miłosierdzia można zastosować w odniesieniu do pastoralnego zagadnienia związanego z osobami rozwiedzionymi żyjącymi w nowych związkach. W żadnym razie nie było to jedyne i centralne zagadnienie ostatniego Synodu Biskupów. Było to tylko jedno z wielu. Nie jest też zagadnieniem nowym. Dyskutowane jest od wielu dziesiątków lat; powstała nie mała biblioteka prac egzegetycznych, historycznych, systematycznych, kanonicznych i innych. Kwestia ta była żywo dyskutowana na Synodzie w Würzburgu (1971-1975). Wówczas to padły słowa o potrzebie uchylenia przez Kościół furtki miłosierdzia.

Synod Biskupów nie poszedł na łatwiznę. Gruntownie podszedł do problemu, choć nie zdołał rozważyć wszystkich szczegółów do końca. Dyskusja nie była łatwa: doszło do konfrontacji stanowisk. Z jednej strony mamy obowiązującą naukę o nierozerwalności małżeństwa sakramentalnego, uzasadnioną w słowie Jezusa (por. Mt 19,6). Żaden biskup nie zakwestionował tej nauki. Pojawiło się jednak pytanie, jak konkretnie zastosować tę zobowiązującą naukę do trudnych, zawiłych, często zaskakujących sytuacji bez naruszenia samej nauki.

Wskazanie podstaw teologicznych stało się tutaj pomocne. Sięgnięto do wielkiego mistrza teologii św. Tomasza z Akwinu. Uchodzi on wszak za doctor communis, za powszechnego nauczyciela. Zawdzięczamy mu wnikliwe refleksje co do stosowania w etyce i prawie Kościoła powszechnie obowiązującej nauki czy powszechnie obowiązujących przykazań w konkretnych i często trudnych sytuacjach. Tomasz powiedział, że nie jest tu możliwe proste, niejako mechaniczne, zastosowanie dedukcji (wywodzenia). Potrzeba raczej kardynalnej cnoty mądrości, czy jak mawiali Grecy, wiedzy (sophrosyne), będącej darem Ducha Świętego (por. S. th. I/II, 57,5; 58,4).

Znany interpretator św. Tomasza Josef Pieper, któremu nie sposób zarzucać progresizmu czy relatywizmu, mądrość rozumie jako sprawiedliwość sytuacyjną (S. th. II/II,47, 3-6). Nie jest ona przebiegłością czy sprytem; nie wywodzi normy z sytuacji, stając się tym samym etyką sytuacyjną. Patrzy ona na poszczególne sytuacje w ich 
jednorazowości, by następnie ocenić je w świetle powszechnie obowiązującej normy oraz celu człowieka. Tomasz idzie tak daleko, że w sytuacjach zawiłych i skomplikowanych zaleca stosować epikeie to jest stosować prawo nie zgodnie $\mathrm{z}$ jego dosłownym brzmieniem, ale zgodnie $\mathrm{z}$ jego duchem i najgłębszym sensem. Tak rozumiana, epikeia nie jest czysto dosłowną sprawiedliwością, ale - jak ją określa Akwinata - wyższą sprawiedliwością (S. th. II/II,120). I tak Tomasz sprzeciwia się czysto pozytywistycznemu, fundamentalistycznemu czy wreszcie na sposób laicki stosowaniu prawa, które nie bierze pod uwagę konkretnego człowieka w jego każdorazowej, indywidualnej jednorazowości, a $\mathrm{z}$ Ewangelii czyni martwe prawo.

Prawo Nowego Przymierza - Ewangelia nie jest - według Tomasza - prawem spisanym, jakąś czystą literą; jest ono raczej darem Ducha Świętego, który ofiarowuje się nam w wierze (por. S. th. I/II, 106,1-2). Przez ten dar Ducha Świętego cnota roztropności, mądrości i sprawiedliwości stają się nadnaturalnie ukształtowaną cnotą, duchowym wyczuciem oraz zdolnością rozróżniania (dlatego w dokumencie Synodu mówi się często o discernimento, łac. discretio). Wielu ojców Kościoła i świętych wypracowało reguły w celu rozróżniania duchów, jak choćby znany z tego św. Ignacy Loyola w Ćwiczeniach duchowych. Dla ojca monastycyzmu Benedykta owa duchowa zdolność rozróżniania - discretio należy do podstawowych cnót mnicha (Regula 64,17-19). Odnosi się to także do biskupa; nie jest on biurokratycznym egzekutorem prawa, ale z przyjaźnią i łagodnością (epikeia) Chrystusa - Łagodnego Sędziego (por. 2 Kor 10,1) winien objaśniać Ewangelię, kierując powierzonym sobie Kościołem.

\section{Synod a duszpasterstwo miłosierdzia}

Synod już się zakończył; otwierając - by tak rzec - drzwi dla możliwości dopuszczenia w poszczególnych przypadkach osób rozwiedzionych żyjących w nowych związkach do sakramentów; jednak nie przeszedł on przez te drzwi. Wskazuje zasadę, ale nie możliwe konsekwencje. W tym punkcie możliwa okazała się większość $2 / 3$ głosów. Nie było to wynikiem podstępnej gry niemieckich biskupów, ale jednogłośna decyzja Komisji Centralnej; nie zamierzała ona 
krępować Papieża, ale pozostawić to jego decyzji. Zwycięzcami Synodu nie są konserwatyści czy progresiści. Właściwym zwycięzcą jest papież. Kierunek jego reform zyskał poparcie większości 2/3. Proces synodalny postępuje. Zamknięcie Synodu stanowi jego istotny etap, choć finalnym i wiążącym momentem będzie dopiero oczekiwana adhortacji Franciszka.

Już teraz jednak można powiedzieć, że Synod odmienił Kościół: przez konsultacje wiernych, przez otwartą kulturę debat, przez akt synodalności, przez fakt, że objawił się nie jako surowy i wygrażający palcem nauczyciel, cenzurujący i potępiający, ale niczym miłosierna Matka otwarty jest dla wszystkich, potrafi się wsłuchiwać, towarzyszy i nieść pociechę. To duszpasterstwo miłosierdzia zaznaczyło się na Synodzie.

Jest ono właściwie rozumianą nową ewangelizacją. Św. Paweł Apostoł w kwestii małżeństwa (por. 1 Kor 7,12-16) zdecydował in favorem fidei (na korzyść wiary). Owo ad favorem fidei jest dziś znowu aktualne. Jeśli rodzice żyjący w tak zwanych małżeństwach nieregularnych na sposób trwały nie zostaną dopuszczeni do sakramentów, wówczas i ich dzieci nie będą miały dostępu do sakramentów. Wtedy stracimy to i następne pokolenie; natomiast miłosierdzie jako nowina przebaczenia i pojednania może otworzyć wierze drzwi, gdzie są one zamknięte.

Wraz z Synodem papież Franciszek ogłosił Rok Miłosierdzia. W centrum Kościoła umieścił to, co stanowi centrum Ewangelii w jej fascynującej nowości. Do tego zaproszeni są wszyscy chrześcijanie. Potrzeba do tego nade wszystko biskupów, którzy na wzór Jezusa okażą się pasterzami sprawiedliwymi i miłosiernymi.

tłum. Rafał J. Kupiszewski 